\title{
Career Decision-Making Self-Efficacy on Mathematics and Science: A Literature Review
}

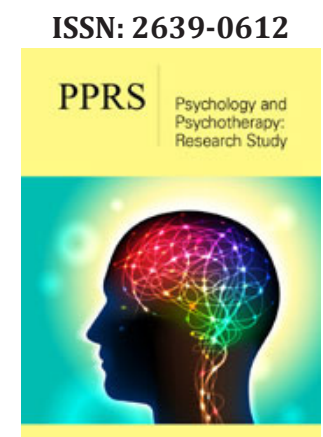

*Corresponding author: Charokopaki K Argyro, Department of Philosophy, Pedagogy and Psychology, Greece

Submission: 唃 November 16, 2019 Published: 監 November 20, 2019

Volume 3 - Issue 2

How to cite this article: Charokopaki K Argyro. Career Decision-Making SelfEfficacy on Mathematics and Science: A Literature Review. Psychol Psychother Res Stud. 3(2).PPRS.000556.2019.

DOI: 10.31031/PPRS.2019.03.000556

Copyright@ Charokopaki K Argyro, This article is distributed under the terms of the Creative Commons Attribution 4.0 International License, which permits unrestricted use and redistribution provided that the original author and source are credited.

\author{
Charokopaki K Argyro* \\ Department of Philosophy, Pedagogy and Psychology, Greece
}

\begin{abstract}
Using social-cognitive career theory as a framework, this article synthesizes pertinent research of career counseling intervention programs on middle school students STEM engagement. It mentions school counseling techniques and activities that have been shown to bring about positive outcomes in promoting STEM self-efficacy, outcome expectations/intentions and goals in career decision making on mathematics/science. Other implications for career and school counselors and counseling practice are also discussed.
\end{abstract}

Keywords: Career decision making self-efficacy on mathematics/science; Career counseling intervention; Middle school students

\section{Introduction}

Several Western countries are faced with lack of students and workers in the so-called STEM fields, i.e. the field of science, technology, engineering and mathematics. Especially the underrepresentation of women, disadvantaged youngsters and ethnic minorities in this field is cause for concern [1,2]. Although the STEM-field is broad, and not all disciplines in the STEM-field are confronted with low enrollment to the same extent, there is cause for concern in engineering, physics and mathematics studies, especially in OECD countries [3] and, therefore, an urgent need to improve the educational and career development of individuals to work in science, technology, engineering and mathematics (STEM) fields. STEM fields are vital to the social and economic condition of all European Countries, contributing to innovations that improve living conditions (e.g. health care, clean energy) and accounting for every country's sustained economic growth [4].

Much of the emphasis and hope to motivating individuals toward STEM has been focused on K-12 and postsecondary formal and informal educators, including out-of-school programs to increase STEM participation [4]. Adolescence is a critical time during development when students are exploring and acquiring academic and career-related interests as well as attitudes and self-beliefs related to their competence in difference domains. Studies on career choice have traditionally focused on youngsters, typically age 16 and older. However, research shows that already at an early age child may develop awareness and (stereotypical) images of and attitudes towards work environments [5-8]. These images and attitudes may have a clear impact on their career choice: they may narrow their options and especially STEM related fields might get excluded. In addition, educational aspirations and achievements before age of 14 are viewed as important precursors of educational choices and occupational aspirations and attainment in adolescence [9]. Students' pathways into and out of STEM careers begin as early as middle school [10].

Impact on students beginning making choices about future coursework in math, science and technology will have long-term implications for their academic and career achievements $[11,12]$. These impacts are more critical considering that during last decade, there are many theoretical approaches in counseling and guidance literature (life-span, career development and psychological approaches) that have underscored that career development is a lifelong process, so the view of researchers and career counselors should broaden from career choice (something that is typically done at an older age, usually middle to late adolescence) to career development (which happens at both younger and older ages) $[7,13,14]$. Career development refers to a longer lasting, a more comprehensive and more dynamic view on how career exploration, awareness, interests, aspirations and expectations develop, and they are affected by societal, socio-economic, educational and family influences [7]. 
Increasing recruitment and retention in the STEM pipeline for young people early, in K-12 schooling, can create a stronger workforce by bringing a range of ideas, experiences, and strengths that are essential for future innovation and excellence. Diversifying the workforce will also provide greater economic opportunities and potential for social mobility to a broader range of E.U. population. In our literature review, we focus in young children of middle school age mostly because career decisions made by young adults have their roots in earlier in childhood. Additionally, in because before late adolescence lies the possibility to broaden the career development process occurring this period. Under this scope, we present the social-cognitive career theory (SCCT) [15], a widely supported model based on Bandura's general social cognitive theory, self-efficacy beliefs and their four sources of information [16] as frameworks and prompts of contemporary researchers to influence study and career choice processes of youngsters. Youngsters need to be exposed to interventions with access to mentoring [17], interventions offering a range of activities and environments under a growth mindset model of three interrelated factors: knowledge, affective value, ability beliefs and self-efficacy building [18]. Such kind of interventions can promote math and science course selection and achievement middle school students, as well as their consideration of math and science careers through raising their self-efficacy in math and science and in career decision making.

\section{Self-efficacy, social cognitive career theory}

Self-efficacy refers to individuals' perceptions about their capabilities for learning or performing tasks within specific domains. Since Bandura $[19,20]$ introduced and construct of self-efficacy, researchers have explored its role in various contexts including career development. In social cognitive theory, self-efficacy is said to influence behaviors and environments and, in turn, is influenced by them $[16,21]$. Two components, personal self-efficacy and outcome expectancy constitute the efficacy beliefs system. Personal selfefficacy is the result of past experiences and can be used to predict future behavior. Outcome expectancies are the anticipated results of a particular behavior, also based on previous life experiences, and may be used to predict future behavior [16]. Students with strong self-efficacy are more likely to set goals and create adaptive learning environments for themselves. Likewise, self-efficacy can be influenced by the outcomes of such behaviors (goal progress, achievement) and by input from environment (e.g. feedback from teachers, social comparisons with peers). Bandura [21] theorized that people acquire their self-efficacy beliefs from sources: interpretations of actual performances, vicarious (modeled) experiences, social (verbal) persuasion, and physiological indexes (emotional arousal). Self-efficacy can influence the choices people make and the courses of action to pursue. Since then, self-efficacy tenets [16] have also been used to understand, more broadly, individuals' vocational behaviors. SCCT [15] is a widely supported model, based on Bandura's general social cognitive theory, and posits that career choice behavior is influenced by outcome expectancies, interests and career self-efficacy.
The theory proposes an interactional influence of external/ environmental factors and individual/cognitive variables on individuals' career development. Within this model, one's background influences one's learning experiences which influence self-efficacy. Self-efficacy shapes one's interest and outcome expectations, which, ultimately, influence career choice [15,22]. Overall, SCCT provides a mechanism of understanding individuals' career-related choices through its focus on self-efficacy ant the ways in which self-efficacy influences behavior. SCCT is particularly useful for understanding the beliefs and career-related choices to pursue or avoid STEM coursework and careers, because of the interplay between the self-efficacy beliefs of students, outcome expectations and their interests or goals.

\section{Stem career self-efficacy}

Within the social-cognitive framework, self-efficacy is believed to be a critical factor for predicting engagement and persistence in the STEM pipeline, especially for female and other underrepresented minority students $[10,23,24]$. Moreover, the fit of the overall SCCT model has been evaluated with raciallyethnic middle and high school boys and girls [25-29]. Hackett \& Betz [30] first used self-efficacy theory in the vocational realm to understand women's avoidance of math and science careers. Recently there is a robust literature related to career self-efficacy expectations, and the findings from exemplary studies help guide and understanding of student STEM career development. There are significant gender differences regarding interest, confidence and beliefs about competence related to math and science learning that emerge during middle school. For example, studies have found that middle school boys tend to have higher self-efficacy and outcome expectations for math and science than do girls [24,31,32].

For females also, the difference in high school course taking is less pronounced, although girls are less likely to take physics than boys [33] and although on the surface this may not seem important, but recent studies have drawn attention to the association between high school physics enrollment and subsequent STEM career engagement [33,34,35]. Performance accomplishments (prior achievements) have been shown to be one of the strongest predictors of self-efficacy and outcome expectations for math and science, especially among African-American and other ethnic minority students $[27,36,37]$. Another important factor in the loss in the STEM pipeline especially for females and ethnic minority students involves differing socialization processes including external sources that may implicitly or explicitly support or discourage STEM engagement [38,39]. For example, from an early age, girls may be influenced by expectations and stereotypes about gender roles that place mathematics-related tasks in a male domain $[13,23,40]$. Additionally, contemporary research findings in high school students within the SCCT framework, provide evidence that background and proximal factors (e.g. familism- loyalty, solidarity, reciprocity and proximal family supports for the decision to pursue a career domain) play a significant role in certain minority students' career development in math and science (Mexican American) [17]. 


\section{Promoting stem career self-efficacy through career counseling interventions}

Research shows that career decision self-efficacy is a malleable construct [41]. As mentioned above, SCCT provides a mechanism for understanding individuals' career related choices through its focus on self-efficacy and the ways in which self-efficacy influences behavior. Additionally, one of the most useful features of SCCT is that the sources of information based to self-efficacy theory that are postulated to lead the development of self-efficacy beliefs can be readily used to guide the development of interventions $[42,43]$. There are four sources of information: Mastery experiences (past performance accomplishments), vicarious learning experiences, physiological states/emotional arousal and verbal persuasions lead to domain-specific beliefs within individuals (which are closely related to behavioral outcomes, e.g. career choices). Many researchers have sought to incorporate one or more of these sources of information in their interventions in order to increase career decision making self-efficacy with some degree of success [44-48].

As mentioned before, adolescence is a critical time during development when students are exploring and acquiring academic and career-related interests as well as attitudes and self-beliefs related to their competence in different domains. Students' pathways into and out of STEM careers begin as early as middle school [32]. As students enter the middle school years, important changes occur in their motivation, self-concept, self-efficacy and achievement [49]. Adolescence is time when students begin making choices about future coursework in math, science and technology that will have long-term implications for their academic and career achievements $[12,48]$. There are findings from exemplary studies that help guide our understanding of student STEM career development, provide evidence about important issues influence the development of student's STEM career self-efficacy and also suggestions for interventions intend to be utilitarian in that they can.

\section{Career counseling interventions}

Early researchers in math \& science self-efficacy beliefs $[50,51]$ have pointed out that successful intervention programs are characterized by their centrality to the mission of the institution (rather than by being an add-on program), by having faculty integrally involved in a program that links a school with a university, and by being primarily oriented to younger children (i.e., elementary or middle school). Fouad [52] first took the initiative to aim at middle school and elementary students, introduced a career intervention program "Career Linking" and reported moderate success but did not document improvements in student attitudes and career decision making. Later on, Fouad \& Smith [50], modified the program, applied it target middle school students and also designed and obtained validity evidence for the middle school selfefficacy scale, a measure of self-efficacy, outcome-expectancy and intentions and goals in career decision making or mathematics/ science.
"Career Linking", 6-week modules, tried to provide students with sources of self-efficacy in career awareness and math and science performance. Students were intensively exposed to a variety of career areas. Each module focuses on a specific career field, in which students are given information about careers, are taken on tours, attend a session with speakers from the career area, and are given opportunities to shadow workers in that career field and to all curricular areas (e.g., history, math, science, and English). Sources of self-efficacy that are explicitly provided include verbal persuasion, vicarious learning, and role models (most of whom are minorities, as are the students). The final source of self-efficacy (performance accomplishments) is not explicitly provided in the intervention. Successful models also is mentioned that focused not only on students' attitudes toward themselves and math and science, but also on teacher and counselor methods and attitudes, on parental and societal expectations [53], make an effort to incorporate culturally relevant material, have a variety of activities, make use of computers, and have high expectations of parental involvement [51].

Outcomes in career awareness intervention programs have included changing students' negative attitudes about math and science, increasing performance levels, increasing exposure to math and science activities, and selecting and delivering good career information [54]. These interventions have been based on Bandura's [16] theory of social cognitions. In a review of K-12 STEM interventions, Valla \& Williams [55] stated that high school interventions target skill development, which provides a gateway into entering advanced studies in math studies in math and science coursework. Contemporary suggestions for interventions [23], rather than providing a list for practice that requires school counselors to provide additional programming or services, intend to be utilitarian in that they can be readily incorporated into career development services already in place in many schools. All intervention suggestions are proposed to be scheduled to target four sources of information of self-efficacy and aim at having a positive impact on important student outcomes (e.g. ultimately, increasing flow of students into the STEM pipeline). They also point out three interrelated factors that, according to literature overview, are crucial in study choice and career development in STEM field and should be considered in designing interventions for students from 8 to 16: knowledge of the STEM field, positive affective value of STEM field and ability and self-efficacy building of STEM related study paths or career options [18]. In the same time, they propose that parents and teachers, with the appropriate training, may play a crucial role in self-efficacy building, by exposing children to a wide range of activities and environments, providing opportunities for task and role model exposure, using growth mindset as model, helping to build knowledge and competence in both boys and girls and by questioning and discussing stereotypical notions surrounding the STEM field [18,23]. Most important, females and students from racial and ethnic minority groups [23] and from low socio-economic status and high-risk populations [18] are underrepresented in STEM fields, so interventions need to 
be targeted primarily towards these specific populations. Most important, once the fit of the overall SCCT model was established as far as math and math and science self-efficacy, interests, intentions and goals, especially for diverse groups of students, attention turned to critical junctures in which to intervene [56].

\section{Career counseling interventions based on four sources of efficacy information}

As far as the four sources of efficacy information and research findings is concerned, the first and most powerful source of information that leads to the development of self-efficacy beliefs, supporting math and science achievement, seems relatively easy to solve. There is considerable evidence that encouraging middle and high students to take rigorous math and science courses and supporting academic achievements in these areas is critical for sustaining STEM engagement $[57,58]$. Programs and interventions that provide opportunities for success in STEM subjects in and out school might be paramount to supporting students' interest and pursuit to STEM career-related interests and goals [24,27,36,37]. In a review of K-12 STEM interventions, Valla \& Williams [55] stated that high school interventions target skill development, which provides a gateway into entering advanced studies in math and science course work.

In fact, it appears to be the optimal way to build self-efficacy. Lopez \& Andrews [37] demonstrated the importance of helping students to have successful experiences in math and sciences, as performance accomplishments were found to be the most powerful sources of self-efficacy. For example, design-based learning, such as designing a solar panel to learn about electricity and environmental science, has proved to be effective for enhancing achievement for lowachieving African American girls [59]. In general, math and science course taking ban be seen as the foundation or set of educational and occupational pathways that lead to STEM careers as in enhances math and science performance [60] because achievement in math and science, will likely foster interest and persistence in pursuing STEM-related goals and aspirations [24,43,61]. In sum, research has shown that math and science coursework is critical for future STEM engagement $[23,55]$. As far as vicarious learning experiences is concerned, exposure to adult mentors who -if possible- are similar to them (e.g. an early adult male but particularly female or male engineer) enhances students' abilities to envision a future identity for themselves, improves STEM confidence and enhances feeling of belonging and engagement. The presence of mentors, role models and social support of learning can be done during career days when guest speakers are invited to attend. Additionally, job shadowing activities and implementation of internship programs at schools or during training in math or science educational course might improve self-efficacy beliefs of students involved [18,19,62] Vicarious learning and activities suggested, can also tackle affective value (perceived barriers) that is adhered to STEM study paths or careers. According to researchers, STEM field suffers from a negative affective value derived from the (false) idea that studies and occupations in STEM fields are predominantly "things and male oriented" and form a threat to more feminine lifestyles or to a good family-work balance [18]. Physiological states/emotional arousal and verbal persuasions are the other two important sources of self-efficacy that can be critical for student STEM engagement and success. In these sources, we should include activities to advance student's awareness of the broad range of vocations, activities and opportunities that the STEM field offers.

This can be done with the presence of mentors or career guidance counselors that can provide information regarding these points and also emphasizing the ways in which STEM careers help people, communities and society. Praise and support from influential adults (mostly parents, especially mothers for the middle school ages and also teachers of an educational course, teachers in school or career counselors) can have a profound effect on students' motivation and outcome expectations for STEM coursework and career development $[29,63,64]$. These can be powerful motivators for students who are interested in helping professions but who may not view STEM jobs in this light. Finally, another strategy that can be included in verbal persuasion source (as far in improving student's performance in math and science), is to promote "incremental theories" of intelligence $[65,66]$. Incremental theories are associated with a growth mind-set that emphasizes the malleability of intelligence and the notion that academic skills can be acquired through effort and practice (rather than existing as innate or "fixed" intelligence). According to these assumptions, we expect that especially those students who regard STEM subjects as not complex and something you need not to put a lot of effort into and also have an implicit theory of intelligence be broadened with aspirations and expectations of STEM pipeline.

In addition to four sources of information, specific techniques that have been shown to bring about positive outcomes should also be incorporated into career interventions. Brown \& Krane [67] in a meta-analysis of career interventions identifying the components that are most influential on participant outcomes, regardless of how the study was conducted, who participated in the intervention and whether it was conducted in individual, group, class or selfdirected formats, mentioned: a) Workbooks and written exercises, b) Individualized interpretations and feedback, c) World of work information, d) Modeling and e) Attention to building support.

Several studies provided support for the effectiveness of career interventions incorporating these five critical ingredients on career decision making $[41,46,68,69]$. Finally, there are also many types of career courses with varying designs, for example, classroombased and computer-assisted and functions, which are effective in enhancing career decision making self-efficacy $[46,68,70,71]$.

\section{Conclusion}

Early adolescent years are an especially critical time in development when students are forming beliefs about themselves as learners along with academic and career related goals. Early perceptions and experiences can impact students' specific areas and academic choices. Intervention programs in the area of STEM career development are important chances to convey information and attitudes and can also help them to improve their academic achievement and self-efficacy, to develop positive outcome 
expectations for STEM coursework and careers. Findings and critical components of interventions and suggestions mentioned provide evidence about the outcomes of interventions sought to incorporate one or more of sources of information. They are also important because to our knowledge there is need for intervention studies incorporate the four sources of information to measure the outcomes of STEM career self-efficacy with emphasis in mastery experiences with math and science achievement [23,72-74].

There is also a need to extend prior efforts by examining a career intervention that incorporates the five critical components mentioned by meta-analysis researchers of interventions $[67,75,76]$ and activities help three critical factors crucial in study choice and career development in STEM field for students enter the middle school years [18]. From the SCCT perspective, the present study of literature demonstrates, that, the SCCT framework is stable and the sources of information based to self-efficacy theory that are postulated to lead the development of self-efficacy beliefs can be used to guide the development of other interventions. The most critical early intervention is to ensure success in math and science classes, or other activities promote math and science (like robotics), that can then serve a gateway into advanced classes and prepare students to entry into University in STEM fields. Longitudinal and experimental research can help identify which interventions are most successful.

\section{Recommendations for Career Counselors and Teachers}

Career counselors should also point to key interventions to help parents, teachers and school counselors to be supportive $[4,23,56]$. This means that they should consider the role of primary school teachers and their crucial role in determining the attitudes and images of students towards science. In doing so, they should design and apply professional development to improve the attitudes of pre-services teachers towards science and technology. They should also consider the role of school counselors, educators and teachers during middle age and their participation in additional intervention programs or their role in services and activities incorporated into their teaching or other career development services already in place in school. Counselors will need to work closely with teachers to promote the integration of the information of the present study into their curricula. The intervention is time consuming because of the time it takes to plan, organize, and coordinate activities of vicarious learning experiences, e.g. tours or speakers. Building a library of printed and audiovisual material helps to have those materials available as teachers need them.

They should also consider that school counselors and teachers also explicit and implicit messages that can have powerful effects on students' dispositions and behaviors, especially in the area of STEM career development. With their messages can also help to counteract possible stereotypical gender, low socioeconomic status or racial/ethnic expectations by encouraging STEM pursuits and by helping students also to improve their academic achievement and self-efficacy beliefs. In the scope of a total framework for multicultural STEM-focused career interventions [4], career counselors, teachers, administrators, and other high school personnel, should consider working with local STEM industries or non-profit groups, such as unions and professional associations, to develop case studies or career biographies of STEM workers, can provide concrete, relatable examples of STEM organizations and diverse STEM pathways to share with middle or high school students [77-80]. They should also provide opportunities to students by partnering with industry, professional societies, foundations, education and training institutions that offer career awareness programs or coordinating STEM career activities and events or local initiatives like the one in the present study that expand STEM learning opportunities.

Finally, educational studies have provided evidence about the importance of curriculum-innovative studies as a promising avenue with regard to STEM related subjects. On career education, guidance and counseling domain, teachers, parents and school counselors should be informed to related STEM career areas and be educated about the impact of their praise and support on motivation and outcome expectations for STEM coursework and career development and informed with regard to opportunities and chances that further education in the STEM-field may offer $[17,18]$. Least but not last, since research provides strong evidence that parents influence outcome expectations and goal intentions of middle school students, especially mothers $[23,56]$, interventions trying to promote math and science career interests should attempt to build parental supports.

\section{References}

1. Organisation for Economic and Development (2008) Encouraging student interest in science and technology studies. Global Science Forum. OECD, France.

2. Watt HMG, Shapka JD, Morris ZA, Durik AM, Keating DP, et al. (2012) Gendered motivational processes affecting high school mathematics participation, educational aspirations, and career plans: A comparison of samples of Australia, Canada and the United States. Dev Psychol 48(6): 1594-1611.

3. Boe MV, Henriksen EK, Lyons T, Schreiner C (2011) Participation in science and technology: Young people's achievement-related choices in late-modern societies. Studies in Science Education 47(1): 37-72.

4. Winston BA (2014) Toward a framework for multicultural stem-focused career interventions. Career Dev Q 62(4): 340-357.

5. Gottfredson LS (1981) Circumscription and compromise: A developmental theory of occupational aspirations (Monograph). Journal of Counseling Psychology 28: 545-579.

6. Gottfredson LS (1996) Gottfredson's theory of circumscription and compromise. In: Brown D, Brooks L (Eds.), Career choice and development ( ${ }^{\text {rd }}$ edn), Jossey-Bass, San Francisco, California, pp. 179232.

7. Hartung PJ, Porfeli EJ, Vondracek FW (2005) Child vocational development: A review and reconsideration. Journal of Vocational Behavior 66(3): 385-419.

8. Watson M, McMahon M (2005) Children's career development: A research review from a learning perspective. Journal of Vocational Behavior 67(2): 119-132.

9. Rojewski JW, Kim H (2003) Career choice patterns and behavior of workbound youth during early adolescence. Journal of Career Development 30(2): 89-108. 
10. Grossman JM, Porche MV (2013) Perceived gender and racial/ethnic barriers to STEM success. Urban Education 49(6): 698-727.

11. Dawes ME, Horan JJ, Hackett G (2000) Experimental evaluation of selfefficacy treatment on technical/scientific career outcomes. British Journal of Guidance and Counseling 28(1): 87-99.

12. Eccles JS (2009) Who am i and what am i going to do with my life? Personal and collective identities as motivators of action. Educational Psychologist 44: 78-89.

13. Lent RW, Brown St D (2013) Social cognitive model of career selfmanagement: Toward a unifying view of adaptive career behavior across the life span. J Couns Psychol 60(4): 557-568.

14. Savickas ML, Nota L, Rossier J, Dauwalder JP, Duarte ME, et al. (2009) Life designing: A paradigm for career construction in the $21^{\text {st }}$ century. Journal of Vocational Behavior 75(3): 239-250.

15. Lent RW, Brown SD, Hackett G (1994) Toward a unifying social cognitive theory of career and academic interest, choice and performance (Monograph). Journal of Vocational Behavior 45(1): 79-122.

16. Bandura A (1986) Social foundation of thought \& action: A cognitive theory. Englewood Cliffs, New Jersey, USA.

17. Garriott PO, Navarro RL, Flores LY (2017) First generation college student's persistence in engineering majors. Journal of Career Assessment 25(1): 93-106.

18. Tuijl CV, Walma J, Vander M (2016) Study choice and career development in STEM fields: An overview and integration of the research. International Journal Technology Des Education 26: 159-183.

19. Bandura A (1977a) Self efficacy: Toward a unifying theory of behavioral change. Psychological Review 84: 191-215.

20. Bandura A (1977b) Social learning theory. Prenctice-Hall, Egnlewood Cliffs, New Jersey, USA.

21. Bandura A (1997) Self Efficacy: The exercise of control. WH Freeman, New York, USA.

22. Lent RW, Brown SD, Hackett G (2000) Contextual supports \& barriers to career choice: A social cognitive analysis. Journal of Counseling Psychology 47(1): 36-49.

23. Falco LD (2017) The school counselor and STEM career development. Journal of Career Development 44(4): 359-374.

24. Lilia H, Norshariani Abd R, Nor Aidillina MR, Ellany ML (2017) Influence of students' STEM self-efficacy on STEM and physics career choice. AIP Conference Proceedings 1923(1): 1-10.

25. Smith PL, Fouad NA (1999) Subject-matter specificity of self-efficacy, outcome expectancies, interests and goals: Implications for the socialcognitive model. Journal of Counseling Psychology 44: 461-471.

26. Flores LY, Navarro RL, De Witz SJ (2008) Mexican American high school student's post-secondary educational goals: Applying social cognitive career theory. Journal of Career Assessment 16(4): 489-501.

27. Garriott PO, Flores LY, Prabhakar B, Mazotta EC, Liskov AC, et al. (2013) Parental support and underrepresented student's math/science interests: The mediating role of learning experiences. Journal of Career Assessment 22(4): 627-641.

28. Navarro RL, Flores LY, Worthington RL (2007) Mexican American middle school students' goal intentions in mathematics and science: A test of social cognitive career theory. Journal of Counseling 54: 320.

29. Turner S, Lapan R (2002) Career self-efficacy and perceptions of parent support in adolescent career development. The Career Development Quarterly 51(1): 44-55.

30. Hackett G, Betz NE (1981) A self-efficacy approach to the career development of women. Journal of Vocational Behavior 18(3): 326-339.

31. Ferry TR, Fouad NA, Smith PL (2000) The role of family context in a social cognitive model for career-related choice behavior: A math and science perspective. Journal of Vocational Behavior 57: 348-364.

32. Fouad NA, Guillen A (2006) Outcome expectations: Looking to the past and potential future. Journal of Career Assessment 14(1): 130-142.

33. Crumb RC, Moore C (2014) The gender gap in high school physics: Considering the context of local communities. Social Science Quarterly 95(1): 253-268.

34. Jurik V, Groschener A, Seidel T (2013) How student characteristics affect girls and boys vergal engagement in physics instruction. Learning and instruction 23: 33-42.

35. Sadler PM, Sonnert G, Hazari Z, Tai R (2012) Stability and volatility of STEM career interest in high school: A gender study. Science Education 96(3): 411-427.

36. Hernandez PR, Schultz P, Estrada M, Woodcock A, Chance RC (2013) Sustaining optimal motivation: A longitudinal analysis of interventions to broaden participation of underrepresented students in STEM. J Educ Psychol 105(1): 89-107.

37. Lopez FG, Lent RW (1992) Sources of mathematics self-efficacy in high school students. The Career Development Quarterly 41(1): 3-12.

38. Phinney JS (2000) Identity formation across cultures: The interaction of personal, societal, and historical change. Human Development 43: 2731.

39. Shapiro CA, Sax LJ (2011) Major selection and persistence for women in STEM. New Directions for Institutional Research 152: 5-18.

40. Milam J (2012) Girls and STEM education: A literature review. Georgia Institute of Technology, Atlanta, Georgia.

41. Lam M, Santos A (2018) The impact of a college career intervention program on career decision self-efficacy, career indecision and decision making difficulties. Journal of Career Assessment 26(3): 425-444.

42. Betz NE (2000) Self-efficacy theory as a basis for career assessment. Journal of Career Assessment 8(3): 205-222.

43. Betz NE (2007) Career self-efficacy: Exemplary recent research and emerging directions. Journal of Career Assessment 15(4): 403-422.

44. Foltz BM, Luzzo DA (1998) Increasing the career decision-making self-efficacy of non-traditional college students. Journal of College Counseling 1(1): 35-44.

45. Luzzo DA, Funk DP, Strang J (1996) Attributional retraining increase career design-making self-efficacy. The Career Development Quarterly 44(4): 378-386.

46. Scott AB, Cianni KD (2008) Effects of an undergraduate career class on men's and women's career decision making self-efficacy and vocational identity. Journal of Career Development 34(3): 263-285.

47. Sullivan K, Mahalik J (2000) Increasing career self-efficacy for women: Evaluating a group intervention. Journal of Counseling and Development 78(1): 54-62.

48. Uffelman RA, Subich LM, Diegelman NM, Wagner KS, Bardash RJ (2004) Effect of mode of interest assessment on client's career decision making self-efficacy. Journal of Career Assessment 12(4): 366-388.

49. Jacobs JE, Lanza S, Osgood DW, Eccles JS, Wigfield A (2002) Changes in children's self-competence and values: Gender and domain differences across grades on through twelve. Child Dev 73(2): 509-527.

50. Fouad NA, Smith PL (1997) Reliability and validity evidence for the middle school self-efficacy scale. Measurement and Evaluation in Counseling and Development 30(1): 17-31.

51. Rendon LI (1985) Preparing Mexican-Americans for mathematics and science-based fields: A guide for developing school and college intervention models. New Mexico State University Press, Las Cruces, New Mexico.

52. Fouad NA (1995) Career linking: An intervention to promote math/ science career awareness. Journal of Counseling and Development 
73(5): 527-534.

53. Seymour E (1995) The loss of women from science, mathematics, and engineering undergraduate majors: An explanatory account. Science Education 79(4): 437-473.

54. Clewell BC, Anderson BT, Thorpe ME (1992) Breaking the barriers. Jossey-Bass, San Francisco, USA.

55. Valla JM, Williams WM (2012) Increasing achievement and highereducation representation of under-represented groups in science, technology, engineering and mathematics fields: A review of current K-12 intervention programs. J Women Minor Sci Eng 18(1): 21-53.

56. Fouad NA, Santana M (2017) SCCT and underrepresented populations in STEM fields: Moving the needle. Journal of Career Assessment 25(1): 24-39.

57. Wang X (2013) Why students choose STEM majors motivation, high school learning, and postsecondary context of support. American Educational Research Journal 50(5): 1081-1121.

58. Mehalik MM, Doppelt Y, Schunn CD (2008) Middle-school science through design-based learning versus scripted inquiry: Better overall science concept learning and equity gap reduction. Journal of Engineering Education 97(1): 71-85.

59. Tyson W, Lee R, Borman KM, Hanson MA (2007) Science, technology, engineering, and mathematics (STEM) pathways: High school science and math coursework and postsecondary degree attainment. Journal of Education for Students Placed at Risk (JESPAR) 12(3): 243-270.

60. Moakler MWJ, Kim MM (2014) College major choice in STEM: Revisiting confidence and demographic factors. The Career Development Quarterly 62(2): 128-142.

61. Erricksen JA, Schultheiss DEP (2009) Women pursuing careers in trades and construction. Journal of Career Development 36(1): 68-89.

62. Gunderson EA, Ramirez G, Levine SC, Beilock SL (2012) The role of parents and teachers in the development of gender-related math attitudes. Feminist Forum 66: 153-166.

63. Turner SL, Stewart JC, Lapan RT (2004) Family factors associated with sixth-grade adolescents' math and science career interests. Career Development Quarterly 53(1): 41-52.

64. Dweck C (2006) Mindset: The new psychology of success. Ballantine Books, New York, USA.

65. Mueller CM, Dweck CS (1998) Praise for intelligence can undermine children's motivation and performance. J Pers Soc Psychol 75(1): 33-52.

66. Brown SD, Krane NER (2000) Four (or five) sessions and a cloud of dust: Old assumptions and new observations about career counseling. In: Brown SD, Lent RW (Eds.), Handbook of counseling psychology ( $3^{\text {rd }}$ edn), Wiley, New York, USA, pp. 740-766.
67. Fouad N, Cotter EW, Kantamneni N (2009) The effectiveness of career decision making course. Journal of Career Assessment 17(3): 338-347.

68. Reese RJ, Miller CD (2010) Using outcome to improve a career development course: Closing the scientist-practitioner gap. Journal of Career Assessment 18(2): 207-219.

69. Folsom B, Reardon R (2003) College career courses: Design and accountability. Journal of Career Assessment 11(4): 421-450.

70. Peng $\mathrm{H}$ (2001) Comparing the effectiveness of two different career education courses on career decidedness for college freshmen: An exploratory study. Journal of Career Development 28(1): 29-41.

71. Betz NE, Hackett G (1983) The relationship of math self-efficacy expectations to the selection of science-based college majors. Journal of Vocational Behavior 23(3): 329-345.

72. Bieschke KJ (1993) A causal model of math/science career aspirations. Unpublished doctoral dissertation., Michigan State University East Lansing, USA

73. Fouad NA, Santanta MC (2017) SCCT and underrepresented populations in STEM fields: Moving the needle. Journal of Career Assessment 27: 6-23.

74. Lent RW, Brown SD, Hackett G (1994) Toward a unifying social cognitive theory of career and academic interest, choice and performance (Monograph). Journal of Vocational Behavior 45(1): 79-122.

75. Lent RW, Lopez FG, Bieschke KJ (1993) Predicting mathematics-related choice and success behaviors: Test of an expanded social cognitive model. Journal of Vocational Behavior 42(2): 223-236.

76. Patel SG, Salahuddin NM, O Brien KM (2008) Career decision making self-efficacy of vietnamese adolescents: The role of acculturation, social support, socioeconomic status and racism. Journal of Career Development 34(3): 218-240.

77. Sheu H, Bordon JJ (2017) SCCT Research in the International Context: Empirical Evidence, Future Directions, and Practical Implications. Journal of Career Assessment 25(1): 58-74.

78. Sheu H, Lent RW (2015) A social cognitive perspective on career intervention. In: Hartung PJ, Savickas ML, Walsh WB (Eds.), APA handbook of career intervention: Foundations. American Psychological Association, Washington, DC, USA, 1: 115-128.

79. Peng H, Herr EL (1999) The impact of career education courses on career beliefs and career decision-making among business college students in Taiwan. Journal of Career Development 25(4): 275-290.

80. Taylor KM, Betz NE (1983) Applications of self-efficacy theory to the understanding and treatment of career indecision. Journal of Vocational Behavior 22(1): 63-81.

For possible submissions Click below: 